\title{
Lewe na apartheid: Lidmate se narratiewe vanuit 'n longitudinale pastorale betrokkenheid
}

\author{
NGTT DEEL 55, NO 1, 2014
}

\section{Foot, Leon M}

Praktiese Teologie, Universiteit van die Vrystaat

\section{Van den Berg, Jan-Albert}

Praktiese Teologie, Universiteit van die Vrystaat

\section{ABSTRACT \\ Living beyond apartheid: narratives of church members from a lon- gitudinal pastoral involvement}

How do white Afrikaans Christians live in post-apartheid South Africa? This question was investigated with members of the Dutch Reformed Church as co-researchers over a period of fourteen years (1998-2012). The Truth and Reconciliation Commission's (TRC) revelations form a backdrop for their stories. Themes include white people's idea of apartheid, guilt and confession, reconciliation and the role of the church. The research is placed within practical theology and specifically in a postmodern paradigm informed and supported by social construction discourse. By using a longitudinal narrative informed methodology a series of group discussions were held in 1998 with co-researchers with the themes mentioned above as focus. In 2012 a series of individual conversations were once again conducted with the same co-researchers focusing yet again on the same themes mentioned above. Despite changes on various levels of South African society very little has changed in the views of the co-researchers during this period. In some cases they have even taken a more racist position than in 1998. The focus in the research is mainly on the Dutch Reformed Church and the process of reconciliation, reintegration and the possible role of the Confession of Belhar in this process.

1 Hierdie artikel is gebaseer op Dr. Leon M Foot se doktorale navorsing met die titel: Lewe na apartheid: Lidmate se narratiewe vanuit 'n longitudinale pastorale betrokkenheid. 


\section{INLEIDING - 'n APARTHEIDSVERHAAL}

Wit Afrikaners kan baie verhale oor hul onlangse geskiedenis vertel, maar as hulle eerlik wil wees, moet hulle veral ook 'n apartheidsverhaal vertel. Daar was uiteraard ook verhale oor die kerk ${ }^{2}$ en kultuur, persoonlike verhale van liefde en leed, maar in al die verhale was die beleid van apartheid die onontkombare, die allesomvattende, allesbepalende faktor in die lewe van alle mense in Suid-Afrika. Niks het in SuidAfrika gebeur wat nie op een of ander wyse deur apartheid aangeraak is nie. Formeel het die bedeling tot' $n$ einde gekom met die verkiesing van 1994.

Sedert dié verkiesing en die afloop van die Waarheids-en-Versoeningskommissie (WVK), het daar reeds byna twee dekades verloop. Hierdie artikel beskryf 'n langtermyn navorsingsprojek (Foot 2013) wat sedert 1998 onder 'n groep wit NG Kerk lidmate in Welkom gedoen is om hulle reaksies op die afskaffing van apartheid oor hierdie tydperk te ondersoek. Die aanvanklike navorsing vind plaas in die tweede semester van 1998, in die tyd waarin die WVK se verslag gepubliseer word. Die opvolgnavorsing vind veertien jaar later aan die begin van 2012 plaas.

Die agtergrond van dié navorsing word gevind in die gegewe dat Suid-Afrika bekend is as 'n baie godsdienstige, en by name Christelike land. In die Vrystaat, waar hierdie navorsing onderneem is, is die persentasie Christene (volgens inligting van die nasionale sensus wat die laaste keer in 2001 oor geloofsoortuiging berig het) onder die algemene bevolking $89.6 \%$ en onder wit mense 'n volle $91 \%$ (Statistics SA 2005:25). Van die kernsake van die Christelike geloof is die opdrag om ander mense soos jouself lief te hê (Matteus 22:39) en ook om aan ander te doen wat jy graag wil hê hulle aan jou moet doen (Matteus 7:12). Die onthullings wat by die WVK gemaak is, plaas onmiddellik wit Afrikaanse Christene se getrouheid aan hierdie uitgangspunte onder verdenking. Voor 1994 het slegs wit mense stemreg gehad waardeur hulle die politieke beleid van die land (help) bepaal het. Die vraag, wat ook die navorsing rigtinggewend beïnvloed het, word daarom onwillekeurig gerig op hoe hierdie wit mense gedink het oor die diskriminerende beleid van apartheid in die lig van hulle godsdienstige belydenis.

Die navorsing word vanuit 'n prakties-teologiese uitgangspunt onderneem om juis die diskrepansie tussen belydenis en praktyk en tussen leer en lewe te ondersoek en te beskryf. Onderliggend aan dié navorsings benadering is die vier kerntake van 'n praktiese teologiese navraag, naamlik die deskriptief-empiriese taak, die

2 In hierdie artikel word die term kerk gebruik om te verwys na die ekumeniese verstaan van die Christelike kerk as die totale liggaam van Christus soos wat dit sigbaar word in die lewe van individuele gelowiges. Die term NG Kerk of soms net Kerk (met 'n hoofletter) verwys na die Nederduitse Gereformeerde Kerk as denominasie. 
interpretatiewe taak, die normatiewe taak en die pragmatiese taak (Osmer 2008:4). Ter uitdrukking van dié prakties teologiese navraag word die narratiewe aard en karakter van die verhale van medenavorsers en die navorser self in die formulering en dokumentering van die navorsing beliggaam en erken. Die navorsing is voorts aan die hand van die momente van 'n narratiewe navorsingsmodel (Müller, Van Deventer \& Human 2001:76-96) ontwikkel, beskryf en gedokumenteer.

In die dokumentering van die navorsingsproses word 'n oorsig enersyds aangebied oor die longitudinale navorsingsproses en -gesprekke met andersyds 'n bespreking van die moontlike betekenis en implikasie van die betrokke perspektiewe soos onder meer aangestip deur medenavorsers. Ter agtergrond word vervolgens 'n opsommende beskrywing gebied van die onthulling van die apartheidsvergrype soos dit voor die WVK afgespeel het.

\section{DIE SOSIALE GEHEIM ONTBLOOT}

In 1996 is die WVK in die lewe geroep om growwe skendings van menseregte te ondersoek (Meiring 1999:12). By die sittings van die WVK was daar onthullings wat koue rillings langs mense se kollektiewe rûe af gestuur het. Vir baie SuidAfrikaners was dit bloot die openbare proklamering van iets wat deel van hulle lewe was (Krog 1998:45). Vir ander, veral vir die wit gemeenskap, was dit 'n groot skok. Verhale van moorde, marteling, ontvoering en ander menseregte-vergrype is vertel (Bell 2001; Krog 1998). In die hoofartikel van Die Kerkbode van 19 Desember 1997 (Gaum 1997:4) verwoord die redakteur waarskynlik die tipiese reaksie van die wit Afrikaanse Christen as hy, met verwysing na die gruverhale, lidmate aanhaal wat sê dat hulle nooit geweet het van, en nooit gestem het vir só 'n beleid nie.

Die "brutale werklikheid" (Campbell 1998:14) van die onthullings van mense wat in diens van die vorige regering was (De Kock \& Gordin 1998), het daagliks die kokon van ontkenning verder oopgebreek. Die aanvanklike selfversekerdheid het oorgegaan in ontkenning, maar ook dit moes plek maak vir ontnugtering en ongeloof. Die sosiale geheim (Imber-Black 1993; Mason 1993) van apartheid is wreed in die openbaar uitgestal (Pauw 1997). 'n Sosiale geheim word gedefinieer as dit waarvan geweet is, of vermoed is, maar nooit oor gepraat is nie. Al gebruik Imber-Black (1993) en Mason (1993) nooit die uitdrukking sosiale geheim van apartheid as sodanig nie, was die onthullende verhale wat een na die ander voor die WVK vertel is, vir baie mense soos 'n sosiale geheim wat skielik aan die hele wêreld ontbloot word. Al te dikwels was dit wit Afrikaners wat as die skuldiges uitgewys is.

Die wit gemeenskap wat jare lank die voordeel van apartheid gesmaak het, is ontnugter. Vrae soos "was ons werklik deel hiervan?" en later "hoe leef ons nou 
verder in die nuwe Suid-Afrika, gegewe ons spesifieke geskiedenis?", het in alledaagse gesprekke en tydens huisbesoeke na vore gekom en het uiteindelik aanleiding gegee tot hierdie navorsing. Die vraag wat Ariel Dorfman (1994:49) na aanleiding van Chili se Rettig-kommissie ${ }^{3}$ vra, is ook die vraag waarmee in die post-apartheid SuidAfrika geworstel word: "How can those who tortured and those who were tortured co-exist in the same land?" Hoe kan bevoordeeldes en benadeeldes van apartheid in een land saam leef? Óf jy moet jou oë sluit vir die werklikheid, óf jy moet die werklikheid erken en die gevolge dra. Krog (1998) vat hierdie dilemma vir NG Kerklidmate goed saam as sy haar boek opdra "aan elke slagoffer wat 'n Afrikaner van op haar lippe gehad het."

Wat waar is van die breë gemeenskap, is soveel te meer waar van die kerk as die gemeenskap wat God se genade sigbaar maak. Hoe kan wit Christene hulle swart broers en susters in Christus in die oë kyk op die pad wat hulle saam loop in die nuwe Suid-Afrika? Dreyer (1996:183) sê tereg dis die uitdaging van die kerk om sy lidmate die geleentheid te gee om nuwe identiteite en nuwe rolle te definieer in die nuwe bedeling.

\section{DIE NAVORSING}

Getrou aan die onderliggende narratiewe aard van die navorsing is persone wat aan die navorsing deelgeneem het, beskou as medenavorsers ter erkenning en uitdrukking van eie unieke en gevalideerde bydraes wat vanuit persoonlik ervarings gelewer is (Morgan 2000:119; Müller, Van Deventer \& Human 2001:76). In hierdie studie was die medenavorsers almal wit Afrikaanssprekende Christene wat bande met die NG Kerk het. As een van die leraars van die NG Gemeente Welkom-Suid, het ek in 1998 'n oop uitnodiging in die gemeenteblad geplaas waarin alle belangstellendes uitgenooi is om deel te word van 'n gespreksgroep oor apartheid en die lewe in die "nuwe" Suid-Afrika. Die aanvanklike groep medenavorsers het mans en vrouens ingesluit. In ouderdom het hulle gewissel van 37 tot 85 jaar met 'n gemiddeld van 49 jaar. Wat beroepe aanbetref was daar - in geen spesifieke orde nie - 'n huisvrou, 'n aantal maatskaplike werkers, 'n aantal persone in die onderwys, drie uit 'n tegniese beroepsveld, 'n pensioenaris en 'n verpleegkundige. Hierdie groep het oor etlike weke vir agt geleenthede bymekaar gekom vir semi-gestruktureerde gesprekke oor die voorkoms en funksionering van apartheid in alle dimensies.

Die navorsing se bedoeling is om weer te gee wat 'n bepaalde groep mense dink en gedink het oor apartheid en verwante sake. Onderliggend aan die navorsingsaanpak

3 Die Rettig-kommissie was die populêre naam vir Chili se Nasionale Kommissie vir Waarheid en Versoening. 
was'n narratiewe geïnformeerde benadering waarin gefokus word op die verhale wat mense vertel asook op die woorde wat hulle gebruik om dit te konstrueer. Ten einde die medenavorsers se narratiewe te kon verwoord, is die gesprekke opgeneem en later getranskribeer. Die identiteit van die medenavorsers is beskerm deurdat elkeen 'n skuilnaam gekry het. Ek het ter uitdrukking van my eie subjektiewe betrokkenheid by die proses ook aan myself as navorser'n skuilnaam toegeken. By een geleentheid het ons ook drie swart gaste ontvang wat aan die gesprek deelgeneem het.

Ten einde sinvol te kan verwys na die woorde van die medenavorsers, het ek 'n stelsel ontwikkel wat die nommer van die gesprek sowel as die reëlnommer aandui. Elke transkripsie is genommer en van reëlnommers voorsien. 'n Aanduiding soos [Danie 3-267] beteken dus dat dit 'n aanhaling van Danie is uit die $267^{\text {ste }}$ reël van die derde gesprek.

Ek wou uitvind of die medenavorsers se sienings oor tyd verander het. Hiervoor was 'n longitudinale "re-study" (Foster, Scudder, Colson \& Kemper 1979:9) nodig. Die aanvanklike navorsing van 1998 is opgevolg deur soortgelyke navorsing in 2012. Vanweë praktiese oorwegings, soos verhuising, was dit nie moontlik om weer die hele groep byeen te bring nie. Ek het egter individuele gesprekke met elkeen gevoer oor dieselfde temas was wat in 1998 aan die orde gekom het. Hierdie gesprekke is weereens opgeneem en getranskribeer. Alle transkripsies is as bylae in die oorspronklike verslag (Foot 2013) opgeneem.

\section{AANVANKLIKE NAVORSING}

Die medenavorsers was dit eens dat hulle niks anders as apartheid geken het nie. Op die vraag oor hoe apartheid in hulle lewe in ingekom het, antwoord Mike [2283] so: Dit het nie in ons lewe ingekom nie, maar ons het in apartheid ingekom. Ter selfdertyd erken hulle ook dat hulle dalk nie krities genoeg gekyk het na die beleid wat so deel van hulle lewe was nie. Van die wreedhede, voer hulle aan, het hulle nie geweet nie: Ben [6-089], die oudste van die medenavorsers, erken: Daar was darem vreeslik baie wreedhede, wat ons as gewone mense nie van geweet het nie, verskriklike ongeregtigheid.

Uit die reaksies van die medenavorsers kan die effek van apartheid beskryf word in terme van vyf breë areas wat vervolgens uiteengesit sal word. Die weergee van die onderskeie temas word nie aangebied as 'n volledige akademiese beskrywing van die verskillende sake nie, eerder as dat dit aanduidend wil wees van herhalende aksente in gesprekke met medenavorsers. Hierdie vyf temas is in die gesprekke genoem en het algemeen onder byna al die medenavorsers voorgekom. Van die opskrifte hieronder verskyn in aanhalingstekens omdat dit getrou aan die narratiewe aard 
van die navorsing, direk ontleen is aan die woorde en metafore soos gebruik deur medenavorsers tydens die betrokke gesprekke.

\section{1 "Twee wêrelde"}

Apartheid het twee wêrelde in een Suid-Afrika geskep. Dit was asof wit en swart in twee verskillende en aparte wêrelde geleef het, terwyl die wit wêreld totaal onbewus was van die swart wêreld. Sello (1998:15) skryf: "Een van die tragiese erflatings van apartheid is dat dit die wit gemeenskap van die res van Suid-Afrika geïsoleer het ..." Hierdie sentiment word geëggo deur Isak [1-609] as hy sê: Ek het so wit grootgeword, hierdie mense is absoluut twee wêrelde van mekaar af.

\section{2 "Minder mens"}

Die een onderliggende beginsel aan apartheid was die idee van 'n inherente meerderwaardigheid van wit mense en 'n gepaardgaande inherente minderwaardigheid van swart mense. Soos Elsa [1-394] dit stel: dit is ... in ons kele afgedruk van kleins af dat swart mense sleg is, dat dit baie moeilik is om daarvan ontslae te raak. Krog (1998:44) beskryf hoe "ordinary people" wat voor die WVK verskyn hulle ervarings verwoord: "We were treated like garbage; worse even than dogs. Even ants were treated better than us" en "How could we lose our humanity like that?"

\subsection{Rassisme}

Rassisme is een van die oorsake van die politieke beleid van apartheid. Vir diegene wat grootgeword het in die tyd van apartheid, was dit terselfdertyd ook'n gevolg van die politieke beleid. De Klerk (2000:33) noem dit dan ook een van die sewe sondes van apartheid. Elsa [3-749] sê: Ons bly dink in terme van wit en swart. Ons dink nie aan mense nie, waarop Johan [3-805] reageer met: Jou definisie kom iets kort. Jou definisie kom daai emosie kort van haat of liefhê. Rassisme is gekoppel aan emosie.

Rassisme is 'n fenomeen wat nie net op interpersoonlike vlak opereer nie. Rassediskriminasie kan ook geïnstitusionaliseerde vorms aanneem. Apartheid was so 'n vorm van rassisme. Villa-Vicencio (1993:133) praat van die "institutionalised racism of apartheid." Die onderliggende uitgangspunt vir rassisme is 'n gevoel van meerderwaardigheid teenoor ander mense. Die idee dat een ras meer werd is, of beter is as 'n ander, is nie 'n nuwe idee nie. In die tyd van wettige slawerny en kolonialisme was die gangbare idee dat Afrika onbeskaafd en ongekultiveerd en daarom minderwaardig teenoor die Weste is (Kasenene 1993:55). 


\subsection{Paternalisme}

'n Vierde gevolg van die sisteem van apartheid was paternalisme. Paternalisme is die gedrag van 'n dominante klas teenoor die ondergeskiktes of gekoloniseerde mense, soortgelyk aan die van 'n pa teenoor sy kind, maar dan 'n kind met beperkte of geen eie vryheid of regte nie. Alhoewel paternalisme ook'n belangrike rol gespeel het in die ontstaan van die beleid van apartheid, was dit - nes rassisme - vir diegene wat groot geword het onder apartheid een van die gevolge van die beleid.

In die gesprekke is verskillende voorbeelde aangebied van paternalisme. Die terrein van die godsdiens is waar paternalisme veral sigbaar was. Frans [1-440] vertel van huisgodsdiens waarheen die swart werkers ingenooi is as hulle daar was om saam met ons huisgodsdiens te hou.

\subsection{Groot en klein apartheid}

Die finale effek van apartheid was die skepping van 'n beperkte en oppervlakkige siening van die beleid in die gedagtes van wit Afrikaners. Wanneer die medenavorsers apartheid bespreek het, was dit gewoonlik in terme van wat genoem word "klein apartheid." Dit was sake soos aparte geriewe wat voorop in die gedagtes van die medenavorsers was: Dit is soos julle sál - julle mag daar sit en nie daar nie en julle moet hierdie toilette gebruik en nie daardie nie [Mike 2-265]. Die wit perspektief begin altyd hier, en eindig gewoonlik ook net hier. Die beleid van apartheid word telkens geëvalueer in terme van alledaagse dinge wat wit mense gehad het of kon doen, maar wat swart mense nie gehad het of kon doen nie. Dit is asof die diskriminasie verwyder kon word deur bloot dieselfde toilette te gebruik!

Selfs wanneer Willem De Klerk (2000:39), politieke kommentator en oud-predikant, krities skryf oor die verkeerdhede van apartheid en hy sommige voorbeelde noem, fokus hy uitsluitlik op sogenaamde klein apartheid: "Gedwonge verskuiwings ... kerkdeure gesluit ... derdeklastreinwaens ... 'net blankes'-bordjies ... aparte ingange ... blankes-alleen sportspanne ...” Die ware tragedie gedurende die tyd van apartheid en nou nog, is dat baie - indien nie die meeste nie - wit Afrikaners nie in staat blyk te wees om die beleid op prinsipiële gronde te evalueer nie. Hulle kyk bloot in die dade vas en vind regverdiging vir hierdie dade sonder om ooit die onderliggende motiewe te beoordeel.

Om egter te erken dat die beleid van apartheid enigsins verkeerd was, bly vir wit mense baie moeilik. Ongeag die argumente wat aangevoer word, blyk dit duidelik dat by baie van die groepslede daar weinig begrip is vir wat apartheid aan swart mense gedoen het. Die onthullings voor die WVK sou egter alle onkunde uit die weg ruim. 


\section{REAKSIES OP DIE WVK}

By die sittings van die WVK is verhaal na verhaal vertel van die misdade wat in die naam van apartheid gepleeg is. Swart mense het begin om hulle narratiewe in die openbaar te vertel en dit is wêreldwyd uitgesaai. Die reaksie wat dit veroorsaak het, kon skaars voorgestel word. Die WVK voorsitter sê dat Afrikaners geskok is, "juis nie deur die leuens nie, maar oor soveel waarheid, soveel aaklighede. Hulle wil dit eerder nie weet nie, eerder glo dis leuens" (Tutu, aangehaal in Retief 1998:15). Tematies sou die volgende verskillende reaksies op die werksaamhede van die WVK verwoord kon word:

Die reaksies op die WVK begin daar waar die onthullings as onwaar afgemaak word. Enersyds is daar 'n volledige ontkenning dat enigiets verkeerds ooit gebeur het. Andersyds is daar diegene wat wel ruimte laat vir 'n beperkte erkenning, maar dit word onmiddellik teengewerk met argumente oor die voordele van apartheid vir die swart inwoners van Suid-Afrika. Daar is ook'n ander tipe ontkenning wat sê dat alhoewel apartheid verkeerd was, dit nie nét verkeerd was nie, maar dat daar tog baie goed uit gekom het (Giliomee 1998:12).

'n Tweede verontskuldigende reaksie op die WVK se bevindinge was die verwysing na die eksterne bedreiging van kommunisme. Johan [4-504] vra: Het iemand al ooit ... die invloed van die kommunisme op ons beeld van dat apartheid so sleg is, gaan bepaal. Hy impliseer dat die wêreldwye veroordeling van apartheid nie so prominent sou gewees het, as dit nie vir die kommunistiese propaganda was nie. Gegewe die agtergrond van sensorskap [Hanlie 2-460], disinformasie (De Kock \& Gordin 1998:119) en breinspoeling [Danie 2-405] gedurende die apartheidsjare, is dit te verstane dat wit mense so 'n vaste geloof gehad het in die sogenaamde Rooi Gevaar.

Die derde reaksie op die WVK is dat die regering die inwoners - lees wit mense mislei het deur die mag wat hulle uitgeoefen het oor die media asook deur direkte intervensies soos die noodtoestande en doelbewuste leuens aan die publiek. Ek is nou nog so verstom dat die Afrikaners so 'n onwrikbare geloof in ons kerkleiers gehad het, en ook ons politieke leiers [Isak 1-612].

Die vierde groep besware teen die onthullings van die WVK handel oor die idee dat dinge in Suid-Afrika tog baie verander het oor die afgelope aantal jare. Johan [3708] sê: Al het jy Nasionaal gestem, het jy nie elke keer vir dieselfde ding gestem nie. By die medenavorsers is daar'n (soms onuitgesproke) erkenning dat baie dinge nie reg was in die tyd van apartheid nie, maar dat dit uitgekanselleer word deur die goeie wat die wit regering teweeggebring het. 
Uiteindelik het een van die medenavorsers, Elsa [6-096], die moed gehad om dit hardop te sê: Ons het die mense basiese menseregte ontneem in hierdie land, hulle het geen sê gehad in hierdie land nie, en as dit nie sonde is nie ... Die een oorweldigende indruk uit die gesprekke in die groep asook uit lesersbriewe aan koerante en in algemene gesprekke, is dat wit Afrikaners graag die boeke oor apartheid sou wou toemaak, om te vergeet wat gebeur het en om oor te begin. Dit voel net vir my dat ons by 'n punt moet kom soos wat jy gesê het dat ons hierdie goed moet afsluit en moet aangaan in die nuwe SA [Frans 1-469].

\section{OPVOLGNAVORSING}

Aan die begin van 2012 het ek al die medenavorsers besoek en in 'n persoonlike gesprek weer die temas van 1998 aan die orde gestel om te bepaal watter, en indien enige, verandering daar by hulle plaasgevind het. In die eerste opvolggesprek, met Elsa, druk sy haar vinger presies op die seerplek van apartheid, naamlik die miskenning van swart mense se menswaardigheid. Dit het nie gegaan oor stemreg of regeer hulle die land nie; die kern was dat swart mense absoluut as niks beskou is [Elsa 9-242]. Die feit dat wit mense'n posisie van meerderwaardigheid teenoor swart mense ingeneem het, hulle menswaardigheid aangetas het en alle selfbeskikking in hulle geboorteland ontneem het, is doelbewus of onwetend geïgnoreer. Die volgende deurlopende temas in die gesprekke met medenavorsers tydens die opvolgnavorsing wys dat hierdie standpunt weinig verander het in die afgelope veertien jaar. Soos ook tydens die rapportering van die gesprekke wat tydens die eerste rondte plaas gevind het, is die meeste van die opskrifte in aanhalingsteken om aan te dui dat dit die eie woorde van die medenavorsers is. Die temas kom ooreen met dié in afdeling 4, maar is nie identies nie as gevolg van die narratiewe aard en karakter van hierdie navorsing.

\section{1 "Apartheid het sin gemaak"}

In antwoord op die vraag oor hoe hulle nou dink oor wat die probleem van apartheid was, was daar vier tipiese reaksies van die medenavorsers en ander wit mense. Die eerste was die argument dat apartheid sin gemaak het. Op die vraag of hy nou anders dink oor apartheid as veertien jaar gelede was Johan [17-043] se nadruklike antwoord: Nee, inteendeel ... Sommige van die voorstaanders van apartheid gaan selfs verder. Só skryf Ludolf Du Toit (2010:elektroniese bron) 'n artikel op die ProAfrikaanse Aksiegroep (PRAAG) se webblad met die opskrif "Apartheid het sin gemaak." Vir hom was apartheid net [l]ogiese menslike gedrag ... om na jou eie om te sien [sy beklemtoning]. 


\section{2 "Dis wetgewing se skuld"}

'n Tweede reaksie was om wetgewing te blameer vir apartheid. In 1998 blameer Mike [2-265] die wetgewing wat bestaande gebruike verpligtend gemaak het. In 2012 handhaaf hy steeds hierdie standpunt as hy praat oor die beleid van apartheid: Dit was in elk geval daar; ons het net ' $n$ wet daarvan gemaak en toe is almal ongelukkig daaroor [Mike 10-248] en dan bevestig hy dit met jy kon nie teen die wet optree nie [Mike 10-260]. Wanneer hy dan 'n voorbeeld gee van wat hy dink apartheid behels het, is dit steeds sake soos ' $n$ blanke man en 'n anderskleurige vrou mag nie saam voor in 'n bakkie gery het nie [Mike 10-245]. Hierdie beperkte siening van wat apartheid behels het, het groot implikasies vir die vraag na skuld en regstelling.

\section{3 "Dit was'n fout"}

Alhoewel daar medenavorsers is wat met 'n baie beperkte definisie van apartheid werk, is daar egter ook van die medenavorsers wat anders na die saak kyk. Hier is dit veral drie persone wat uitstaan in hulle mening, naamlik Elsa, Hanlie en Isak. Elsa [3-145] het byvoorbeeld in 1998 reeds gesê: Ek dink apartheid het die swartmense heeltemal ver- "ontmens" en in die 2012 navorsing gebruik sy steeds hierdie woord: Ek dink apartheid... het mense heeltemal ontmens. Dit het van mense diere gemaak, of goed. Hulle was nie mense nie. Ek dink dit is die verskriklikste ding ... [Elsa 9-238].

\section{4 "Twee wêrelde"}

'n Verdere tema wat in die aanvanklike navorsing na vore gekom het, is die twee wêrelde waarin wit en swart in SA bly. Die kontak was grootliks beperk tot die werksituasie waar dit gewoonlik die swart persoon was wat'n ondergeskikte posisie ingeneem het. Volgens die 2011 SA Versoeningsbarometer is Suid-Afrikaners steeds geskei op grond van taal, etnisiteit en ras (NPC 2011:elektroniese bron).

Wat wel gebeur is dat die blootstelling by die werk en in die openbare lewe dramaties vermeerder het. George [15-037] vertel van sy swart kollegas wat geleidelik deel van sy werkswêreld geword het. Die beste van alles sê hy: Dit is 'n ding wat spontaan gebeur het, dit was nie gedwonge nie. Op 'n meer persoonlike vlak was die noue kontak met ander rasse ook nie altyd so maklik nie. Frans [9-072] het sy kinders redelik liberaal grootgemaak, maar toe sy dogter met 'n bruin man uitgaan, toe dit naby aan my bas kom, toe is dit' $n$ ander storie.

\subsection{Rassisme}

Rassisme wat in 1998 prominent was, is steeds 'n faktor om mee rekening te hou. Die meeste medenavorsers sal, soos waarskynlike die meeste ander mense ook, sê 
dat hulle nie rassiste is, of ten minste nie wíl wees nie. Ek sou sê ek is minder rassisties as vroeër [Isak 16-190] of Dit is net nog 'n mens [Frans 9-093].

Daar is al meer getuienis dat ten minste sommige mense doelbewus daarna strewe om nie meer rassisties te wees in hulle optrede nie. Karin [18-029] verklaar: Ek sien alle mense ongeag van ras of geslag as mensekinders wat deur God geskape is. Elsa [9-436] sê: Met my hele diepste wese wil ek nie 'n rassis wees nie en ook Isak [16-174] se voorneme is duidelik: Ek het doelbewus besluit om my gedagtes en denke nie deur rassisme te laat oorheers nie. En tog is dit moeilik om by hierdie voorneme te hou. Sommige van dieselfde medenavorsers waarna hierbo verwys is, erken ruiterlik dat hulle sukkel om konsekwent nie-rassisties op te tree. Isak [16-174] sê: Ek sou genoeg redes kon vind om rassisties te wees, en om meer rassisties te word.

Op die vraag hoekom sekere mense klaarblyklik tans meer rassisties is as vroeër antwoord Isak [16-194] so: Ons sien die effek van misdaad, korrupsie, swak dienslewering, politici se uitsprake. Die plaasboere is onder bedreiging en onveilig. Regstellende aksie. Van die rááksien van hierdie probleme is dit dan 'n kort sprong om 'n ras-kleur daaraan te gee.

\subsection{Skuld vir apartheid}

'n Laaste tema wat uit die aanvanklike navorsing kom, is die aanvaarding van die verantwoordelikheid vir skuld. Skuldbelydenis oor wat apartheid aan ander gedoen het, is onmoontlik, omdat ons eintlik nie geweet het nie [Hanlie 12-274]. Terwyl sommige medenavorsers bereid is om te erken dat daar fout was, is daar ander soos Danie wat nie eers wil praat oor wat fout was met apartheid nie. Hy wil net sorg dat die blaam op Verwoerd [Danie 13-552] val, of op Van Riebeeck en die Engelse [Danie 13-488]. Om te erken dat daar fout was met apartheid is vir hom net om vir die ander groep 'n stok gegee om mee te slaan [Danie 13-534]. Ook Johan [17-112] voel nie skuldig nie: Ek sal nooit erken en daarom nooit bely dat afsonderlike ontwikkeling 'n sonde was nie en daarom het ek nie skuld nie. Karin [18-191] probeer ten alle koste ook die ander rasse betrek by dinge wat dalk verkeerd was in die verlede en dan voeg sy by dat daar ook positiewe gebeurtenisse [Karin 18-278] was. Danie [13-502] stel dit pertinent: ek voel geensins skuldig in enige sin vir apartheid nie en George [15-568] eggo hierdie woorde: Ek voel nie ek het skuld aan apartheid nie. Waar daar wel sprake van belydenis is, word dit bloot vergeestelik as jy voor God vergifnis gevra dan is dit mos nou klaar [Linda 13-517].

Wanneer erken word dat apartheid swart mense benadeel het, is dit onvermydelik dat een of ander vorm van regstelling wel moes gebeur. Onder die medenavorsers is dit egter nie 'n eenvoudige saak nie. Johan [5-635] glo nie aan die meriete van 
regstellende aksie nie. Vir hom is dit bloot omgekeerde rassisme: Regstellende aksie behoort op meriete gebaseer te word. Ander [Isak 5-589] is ook skepties oor die waarde van sulke aksies: Op die korttermyn kan ons 'n paar sake regstel, maar op die langtermyn gaan niemand daarby baat nie. By een mede-navorser [Danie 13-116] was daar in 2012 'n bitterheid wat nie in 1998 daar was nie. Vir ander is dit ' $n$ realiteit en 'n gegewe in die NSA. Teen die agtergrond van apartheid is regstellende aksie 'n logiese (hoewel steeds diskriminerende) praktyk [Isak 16-301].

\section{DIE PAD VORENTOE}

Die meeste van die medenavorsers gebruik woorde soos positief [Frans 9-850], hoop [Elsa 9-895], ons probeer [Johan 11-212] en ons vorder [Isak 14-401] wanneer hulle praat oor die toekoms van Suid-Afrika. Johan [17-029] is dalk die eerlikste as hy sê dat hy die veranderings as onvermydelik aanvaar en daarby probeer aanpas. Elsa [9898] verraai tog, te midde van baie optimisme oor die toekoms, 'n stukkie nostalgie as sy sê: Sal miskien nooit weer heeltemal wees soos in die tyd toe die blankes regeer het nie.

Ten spyte van hierdie positiewe houding ten opsigte van die toekoms, spreek die medenavorsers hulle uit oor kwessies wat hulle meen dit vir hulle moeilik maak om positief te bly oor die toekoms van Suid-Afrika. Vir Karin [18-315] is daar talle voorbeelde van uiters patetiese diens, arrogansie en Babelse verwarring. Johan is bekommerd oor die vertroue tussen wit en swart. Hy sê reguit dat die twee groepe mekaar nooit sal vertrou solank daar nog Malemas rondloop nie [Johan 17-219]. Ten spyte van Danie [13-292] se geloof dat God nog 'n taak vir die wit mense hier het, klink hy tog heel sinies as hy praat oor Suid-Afrika: Ons sit met korrupsie, die hoogste in die wêreld, ons sit met moord en doodslag, die hoogste in die wêreld. Korrupsie speel ook by van die ander 'n rol: Ek begin mense wantrou vanweë die geweldig baie bedrog. Van mense wat in vertrouensposisies is [Karin 11-246].

\section{PERSPEKTIEWE OOR DIE TAAK EN ROL VAN DIE NG KERK}

'n Kritiese buitestaander kan verstaan dat lidmate groot probleme met die NG Kerk het. Frans en van die ander medenavorsers sou kon identifiseer met die standpunt van Meyer en Naudé (1994:169) wanneer hulle die NG Kerk beskuldig van 'n dualistiese Christenskap. Die fokus was amper eensydig op die gelowige se persoonlike verhouding met God en die implikasies wat dit het vir die leefwêreld van die gelowiges, is nie verreken nie. Later sou die NG Kerk erken dit was té lank té teoreties besig met die apartheidskwessie (Ned Geref Kerk 1990:39). In die eerste gesprek verwoord Frans [1-444] sy probleem met die NG Kerk so: Dit voel vir my ... 
asof ons amper' $n$ geestelike rat voor die oë gedraai is, want dit [apartheid] is wat reg is, dit is soos dit moet wees. Volgens die kritiek van die Sendingkerk was apartheid se uitgangspunt die onversoenbaarheid van mense en daarom moes hulle apart gehou word - ook in die kerk: "Die politieke en kerklike bestel van Suid-Afrika is 'n bestel waarin onversoenbaarheid tot 'n samelewingsbeginsel verhef word" (NG Sendingkerk 1982:elektroniese bron).

Die NG Kerk het teen 1998 wegbeweeg vanaf'n posisie waarin aanvanklik na die kerk verwys is as "die Nasionale Party in gebed" (Giliomee 1979:240) tot 'n afwysing van die beleid van apartheid in Kerk en Samelewing 1990 (Ned Geref Kerk 1990). Dit het uitgeloop op professor Willie Jonker se skuldbelydenis namens die NG Kerk en die Afrikaners by die kerkeberaad in Rustenburg. Die sitting van die Algemene Sinode van 1994 was bekend as die "sinode van versoening" omdat mense soos professor Ben Marais en doktor Beyers Naudé wat vroeër 'n koue skouer van die Kerk gekry het, nou hartlik ontvang is. Ook die eerste nuwe president van 'n demokratiese SuidAfrika, meneer Nelson Mandela is 'n spreekbeurt gegee. Die sinode het ook kennis geneem van die stigting van die VGKSA en het besluite geneem oor die "daarstelling van een kerkverband" (Ned Geref Kerk 1994:442). Vier jaar later het die volgende Algemene Sinode die Kerk weer verbind om "een kerkverband tot stand te bring" (Ned Geref Kerk 1998:422).

In die 1998 navorsing was daar veral twee kwessies rondom die NG Kerk wat sterk na vore getree het. Die een was dat die NG Kerk vir jare lidmate mislei het deur die beleid van apartheid teologies te regverdig [Frans 1-456]. Die tweede was dat die NG Kerk aan die slaap was vir soveel jare [Danie 4-466] en nooit die onreg, die spreekwoordelike olifant in die kamer, raakgesien het nie.

Tydens die opvolgnavorsing was dit veral Elsa en Frans wat baie negatief is oor die rol van die NG Kerk. Ek wil net sê dat die twee mense wat hier sit, wat jy in hele ander hoedanigheid geken het, gaan glad nie meer kerk toe nie. [Frans 9-747]. Beide van hulle was op 'n stadium kerkraadslede wat baie betrokke was in die werksaamhede van die NG Kerk. Die rede vir hulle standpunt is duidelik uit hulle antwoorde op die vraag of die NG Kerk'n rol speel in versoening: Nee, hulle doen nie [Frans 9-754] en: Ek glo nie regtig so nie [Elsa 9-756]. Sy beskryf die Kerk as 'n plek waar jy nie hoor dat apartheid 'n euwel was nie. Dit is asof niks daar verander het nie. Die NG Kerk is "oop" maar daar is steeds nie bruin of swart mense daar nie, die gesindheid is nog nie oop nie [Elsa 9-786]. Oor versoening sê Frans [9-760]: Ek glo nie die kerk speel'n rol nie. Ek dink die kerk trap water.

As die kerk nie weer daarvan beskuldig wil word dat hy aan die slaap is nie, sal die kerk doelbewus lidmate moet leer dat alle mense menswaardig behandel moet word 
ongeag van kleur. Die kerk kan nie langer sy oë toemaak vir hierdie olifant in die kamer nie.

Die kerk sou 'n rol daarin kon speel om lidmate te begelei tot belydenis en versoening, maar reeds in die eerste gesprek is daar frustrasie met die NG Kerk uitgespreek [Frans 1-459]. In die opvolgnavorsing is Frans [9-771] steeds van mening dat die Kerk nie 'n positiewe rol speel nie. Elsa [9-782] noem dit 'n klub waaraan sekere groepe mense behoort wat graag soontoe wil gaan. Danie [13-323] is selfs nog meer sinies oor die Kerk: Ag weet jy ek dink die kerk het nie 'n rol gespeel in die tye van apartheid nie en die kerk speel nie 'n rol ... Isak [16-426] trek die lyne van die kritiek op die NG Kerk saam as hy sê: Ek wil egter glo dat apartheid die kerk in 'n integriteitsen geloofwaardigheidskrisis gedompel het.

Konkreet sou kerkhereniging en die rol van die Belydenis van Belhar genoem kon word. Die Belydenis dra vir verskillende mense verskillende gewig. Danie [13562] distansieer homself geheel en al van die belydenis: Hulle moet dit los, dit is 'n afgeforseer belydenis wat vir my niks beteken nie terwyl dit vir Linda [13-571] bloot mensewerk is - asof die ander belydenisskrifte nie ook mensewerk is nie: Dit is 'n belydenis wat deur mense geskryf is en ons bely 'n lewende God. Isak [14-330] beskou Belhar as 'n sweep om NGK mee te slaan wat besig is om ' $n$ wig in te druk wat onnodig is [Isak 14-318]. Teenoor hierdie afwysende houdings vra Hanlie [12-691] reguit: wat is daar in Belhar om nie te aanvaar nie?

\section{HIERVANDAAN VERDER}

In 'n sekere sin bied die voorafgaande gerapporteerde perspektiewe net 'n wegspringplek vir verdere navorsing. Benewens die aangeduide temas sou 'n volgende navorser in meer diepte kon ondersoek instel na die rol van die NG Kerk in die pastorale begeleiding van lidmate in 'n post-apartheid Suid-Afrika tot verdere fasilitering van die tema van versoening.

\section{BIBLIOGRAFIE}

BELL, T. 2001. Unfinished business: South Africa, apartheid and truth. Observatory: RedWorks.

CAMPBELL, C. 1998. PW and the Afrikaner. Whose guilt is it anyway? Cape Argus 5 June, p. 14.

DE KLERK, W.J. 2000. Afrikaners: Kroes, kras, kordaat. Kaapstad: Human \& Rousseau. 
DE KOCK, E. \& GORDIN, J. 1998. A long night's damage: Working for the Apartheid state. Johannesburg: Contra Press.

DORFMAN, A. 1994. Death and the maiden. 2nd ed. London: Nick Hern Books.

DREYER, T.F.J. 1996. Praktiese kerkwees in die nuwe Suid-Afrika. Hervormde Teologiese Studies 52(1):179-189.

DU TOIT, L. 2010. Apartheid het sin gemaak. 6 Januarie. Bekom op 28 Junie 2012 by: http://www.praag.co.za/feuilleton-magazine-386/opstelle-magazine-389/6903apartheid-het-sin-gemaak.html

FOOT, L.M. 2013. Lewe na apartheid: Lidmate se narratiewe vanuit 'n longitudinale pastorale betrokkenheid. $\mathrm{Ph} . \mathrm{D}$. tesis, Universiteit van die Vrystaat, Bloemfontein.

FOSTER, G.M., SCUDDER, T., COLSON, E. \& KEMPER, R.V. (EDS.) 1979. Long-term field research in social anthropology. New York: Academic Press.

GAUM, F.M. 1997. Nie na die mond praat nie. Die Kerkbode 7 Maart, p. 6.

GILIOMEE, H. 1979. Afrikaner politics: How the system works. In: Adam, H. \& Giliomee, H. (eds.), The rise and crisis of Afrikaner power. (Cape Town: David Philip), pp. 196-257.

1998. Die bitter én soet van apartheid. Insig Mei, p. 12-21.

IMBER-BLACK, E. 1993. Secrets in families and family therapy: an overview. In: Imber-Black, E. (ed.), Secrets in families and family therapy (New York: Norton), pp. 3-28.

KASENENE, P. 1993. Response: Human dignity, identity and decolonising the mind. In: Waijaki, M., Turaki, Y., Van der Walt, B.J. \& Kasenene, P. (eds.), Visions of man and freedom in Africa (Potchefstroom: IRS), pp. 53-63.

KROG, A. 1998. Country of my skull. Johannesburg: Random House.

MASON, M. 1993. Shame: reservoir for family secrets. In: Imber-Black, E. (ed.), Secrets in families and family therapy (New York: Norton), pp. 29-48.

MEIRING, P.G.J. 1999. Chronicle of the truth commission: A journey through the past and present - into the future of South Africa. Vanderbijl Park: Carpe Diem. 
MEYER, R. \& NAUDÉ, B. 1994. The Christian Institute of South Africa: a short history of a quest for Christian liberation. In: Liebenberg, I. et al (eds), The long march: The story of struggle for liberation in South Africa (Pretoria: HAUM), pp. 164-172.

MORGAN, A. 2000. What is narrative therapy? An easy-to-read introduction. Adelaide: Dulwich Centre Publications.

MÜLLER, J., VAN DEVENTER, W. \& HUMAN, L. 2001. Fiction writing as metaphor for research: A narrative approach. Practical Theology in South Africa.16(2):76-96.

NED GEREF KERK 1990. Kerk en Samelewing: 'n Getuienis van die Ned Geref Kerk 1990. Bloemfontein: Algemene Sinodale Kommissie.

1994. Handelinge van die Algemene Sinode.

1998. Handelinge van die Algemene Sinode.

NED GEREF SENDINGKERK 1982. Die NG Sendingkerk en apartheid: 'n prinsipiële besinning. Bekom op 7 Mei 2012 by: http://upetd.up.ac.za/thesis/ available/etd-04012009-233502/unrestricted/07back.pdf

NPC 2011. National Planning Commission: Diagnostic Overview. Accessed on 16 July 2912 at: http://www.npconline.co.za/MediaLib/Downloads/Home/Tabs/Diagnostic/ Diagnostic\%200verview.pdf

OSMER, R.R. 2008. Practical Theology: An introduction. Grand Rapids: Eerdmans.

PAUW, J. 1997. Into the heart of darkness: Confessions of Apartheid's assassins. Johannesburg: Jonathan Ball.

RETIEF, H. 1998. As mens sê hy’s jammer, dan is daar geen `ja, máár... nie. Rapport 23 Augustus, p. 15.

SELLO, S. 1998. Ons moet verby wit en swart kyk. Rapport 22 Maart, p. 15.

STATISTICS SA 2005. Census 2001 Primary tables Free State. Accessed on 21 March 2011 at: http://www.statssa.gov.za/census01/html/FSPrimary.pdf

VILLA-VICENCIO, C. 1993. The spirit of hope: Conversations on religions. Johannesburg: Skotaville Publishers. 


\section{TREFWOORDE}

Apartheid

Longitudinaal

Narratief

Nederduitse Gereformeerde Kerk

NG Kerk

Rassisme

Skuld

Versoening

Welkom, Vrystaat

Wit

WVK

\section{KEY WORDS}

Apartheid

DRC

Dutch Reformed Church

Guilt

Longitudinal

Narrative

Racism

Reconciliation

TRC

Welkom, Free State

White 


\section{KONTAKBESONDERHEDE}

Dr Leon Foot

Fakulteit Teologie

Departement Praktiese Teologie

Universiteit van die Vrystaat

Posbus 339

9300 BLOEMFONTEIN

E-pos: leon.foot@telkomsa.net

Prof J-A van den Berg

Fakulteit Teologie

Departement Praktiese Teologie

Universiteit van die Vrystaat

Posbus 339

9300 BLOEMFONTEIN

Sel: 0832972619

E-posaders: vdbergja@ufs.ac.za 